\title{
Body and Sexuality: Puerperas' Experiences ${ }^{1}$
}

\author{
Natália Rejane Salim² \\ Natalúcia Matos Araújo ${ }^{3}$ \\ Dulce Maria Rosa Gualda ${ }^{4}$
}

The aim of this study was to determine how women deal with sexuality and bodily changes during the puerperium. A qualitative methodology was used and a semi-structured interview with a leading question script was chosen as the research tool. Six puerperas from the west area of São Paulo (Brazil) took part in this study. The interviews were accomplished at their homes. In analysis, the responses were grouped into three main categories: "Changes", Sexuality" and "Social Support". The study results revealed that during this period there are important changes. Sexuality has been shown to evolve many difficulties, fears and worries. The relationships with the person's partner and support network have revealed themselves as being of great importance. It can be concluded that the puerperal period evolves in terms of many transformations in the emotional and psychosocial areas. Thus it is necessary for health professionals who deal with women's care to value this period.

Descriptors: Postpartum Period; Sexuality; Human Body.

\footnotetext{
${ }^{1}$ Basic Scientific Research Project (modality Brazilian research) "Sexualidade no Puerpério" - PIBIC/INSTITUCIONAL, Process \# 2350 (2007/2008)

2 Obstetrics Undergraduate Student, Escola de Artes, Ciências e Humanidades, Universidade de São Paulo, SP, Brazil. E-mail: jenat@usp.br.

${ }^{3}$ RN, Ph.D. in Nursing, Professor, Escola de Artes, Ciências e Humanidades, Universidade de São Paulo, SP, Brazil. E-mail: natalucia@usp.br.

${ }^{4}$ Nurse-Midwife, Ph.D. in Nursing, Full Professor, Escola de Enfermagem, Universidade de São Paulo, SP, Brazil. E-mail: drgualda@usp.br.
}

Corresponding Author:

Dulce Maria Rosa Gualda

Universidade de São Paulo. Escola de Enfermagem

Rua Enéas de Carvalho Aguiar, 419

Bairro Cerqueira Cesar

CEP: 05403-000 São Paulo, SP, Brasil

E-mail: drgualda@usp.br 


\title{
Corpo e sexualidade: a experiência de um grupo de puérperas
}

Este estudo teve como objetivo conhecer como as mulheres lidam com a sexualidade e as mudanças corporais no período puerperal. Trata-se de pesquisa de abordagem qualitativa. $O$ instrumento de trabalho foi a entrevista semiestruturada. Seis puérperas, moradoras da zona oeste de São Paulo, participaram do estudo. As entrevistas foram gravadas no domicílio das participantes. Na análise, as falas foram agrupadas em categorias, visualizaram-se três categorias principais: mudanças, sexualidade e suporte social. Os resultados revelaram que nesse período ocorrem mudanças importantes. A sexualidade mostrou-se, muitas vezes, envolvida por dificuldades, medo e preocupações. O relacionamento com o parceiro e com a rede de apoio revelou importância. Pode-se concluir que o puerpério é envolvido por muitas transformações, tanto no âmbito físico como psicossocial. Dessa forma, torna-se necessária a valorização desse período pelos profissionais que atuam diretamente no cuidado à mulher.

Descritores: Período Pós-Parto; Sexualidade; Corpo Humano.

\section{Cuerpo y sexualidad: experiencias de puérperas}

\begin{abstract}
Este estudio tuvo como objetivo conocer como las mujeres se relacionan con la sexualidad y los cambios corporales en el período del puerperio. Se trata de una investigación cualitativa; el instrumento de trabajo fue la entrevista semiestructurada. Seis mujeres del oeste del estado de Sao Paulo (Brasil) participaron del estudio. Las entrevistas fueron grabadas en los hogares de las participantes. En el análisis, las conversaciones fueron agrupadas en categorías, las tres principales fueron: "Cambios", "Sexualidad" y "Apoyo Social". Los resultados muestran, que en ese periodo ocurren importantes cambios. La sexualidad se mostró relacionada, muchas veces, con dificultades, miedos y preocupaciones. La relación con el compañero y con la red de apoyo demostró ser importante. Se puede concluir que en el puerperio ocurren muchos cambios, tanto en el ámbito físico como en el psicosocial. De esta manera los profesionales, que trabajan directamente con las mujeres, deben dar valor a este período.
\end{abstract}

Descriptores: Periodo de Posparto; Sexualidad; Cuerpo Humano.

\section{Introduction}

The puerperium, the period that begins after childbirth, is marked by changes, the purpose of which is to restore a woman's body and systems to their pre-pregnancy state. The start of the puerperium takes place one to two hours after the expulsion of the placenta, though when it comes to an end cannot be precisely forecast, because during the postpartum period a woman undergoes changes and these changes do not occur only in the physiological, endocrinal and genital domains, but in her whole person(1).

We cannot speak of the wholeness of a woman without talking about her body and sexuality. It is the body that permits the expression of sexuality. The body which belongs to an individual who is fed, clothed, kept clean, and goes through daily routines is a cultural agent and a locus of social control(2). Thus, body and sexuality are interlinked social constructs. Also, although sexuality is intimately bound to our beliefs and imaginations, it is not limited to the physical body ${ }^{(3)}$.

Expressions of sexuality have different meanings, in accordance with the values in force in each sociocultural stratum. Sexual scripts provide evidence of the varied and diverse types of socialization with which the individual experiments during his or her 
life: family, types of school, access to various means of communication, networks of friends and neighbors. These forms of socialization will play a fundamental role in the construction of the individual as a whole, and generate ways of interpreting sexual relations and the form in which sexuality is experienced ${ }^{(4)}$.

The experience of the puerperium is undoubtedly complex, for it brings in its train bio-psycho-social changes to women and these changes are filled with new meanings that can interfere with the way women adapt to motherhood. Becoming a mother is a rite of passage and involves a woman in reorganizing her various roles.

Although the puerperium is a noteworthy event in the lives of women it is a period, in general, that is neglected. By far the most attention is paid to the babies and there is an expectation that women take on the role of mother immediately and without difficulty. With regard to their sexuality, there are important adjustments that need to be made.

Given that sexuality is an important aspect of women's lives, and since we know about the bodily changes that occur in the postpartum period and about the impact that these changes may have, it is of the utmost importance to understand and learn of their experiences once they are seen as having unique expressions for each and every woman in their puerperium. Thus the aim of this study is to understand how women deal with their bodies' changes and their sexuality during the puerperium and therefore this was the leading question: "How do the women deal with their sexuality and body changes during the puerperium?"

\section{Methods}

The approach this study took was qualitative and the methods used to collect data were through observation and interview. Observation is what enables the researcher to get close to the subjects and to get to know their social contexts, which allows the interviews to be held(5).

Six women took part in the study. The criteria to participate of the study were: women who were in remote puerperium, who had a single fetus pregnancy and natural childbirth, with or without perineal trauma. The sample number was determined when considering the women's answers and the established objectives.
The women who took part in this research were contacted during the immediate puerperium in the Hospital e Maternidade Amador Aguiar (Amador Aguiar Maternity Hospital) in Osasco, São Paulo. Thereafter, the interviews were scheduled as per the wishes and availability of each of them during remote puerperium, namely, after the forty-third postpartum day. These were conducted by home visit at around 55 days post-partum, which made it possible to get to know the context in which the women live and some of their family dynamics and relationships. The interviews were recorded with the consent of the women and lasted on average 60 minutes.

First of all, the interviews were transcribed and thereafter they were placed into categories. In order to categorize them, the accounts of the perceptions of each woman interviewed were grouped with regard to the matters addressed. Based on these categories and immersion in the data, the next stage was to develop themes.

The data analyses and interpretation were based in study(6), and focused through Thematic Contents Analyses. We first understood the data through material readings and re-reading. Then we moved to the exploration phase, at the end of which we have identified and analyzed the senses nuclei and gathered the parts of the text by the discovered themes. We have articulated it within the study aims during all points of the process.

The research project was approved by the Research Ethics Committee of the School of Nursing, University of São Paulo, and met the requirements of Resolution 196/1996 of the National Council for Health.

First, authorization was requested from the Directorate of the hospital where first contact was made with the women and interviews scheduled. The interviews were recorded with the consent of the women. All the women who took part in the study signed a Free and Informed Consent Agreement and received a copy of it. Their identities were protected and their participation in the investigation was optional.

\section{Results}

The content of the interviews was grouped into categories according to thematic similarity, as presented in a schematic form below: 


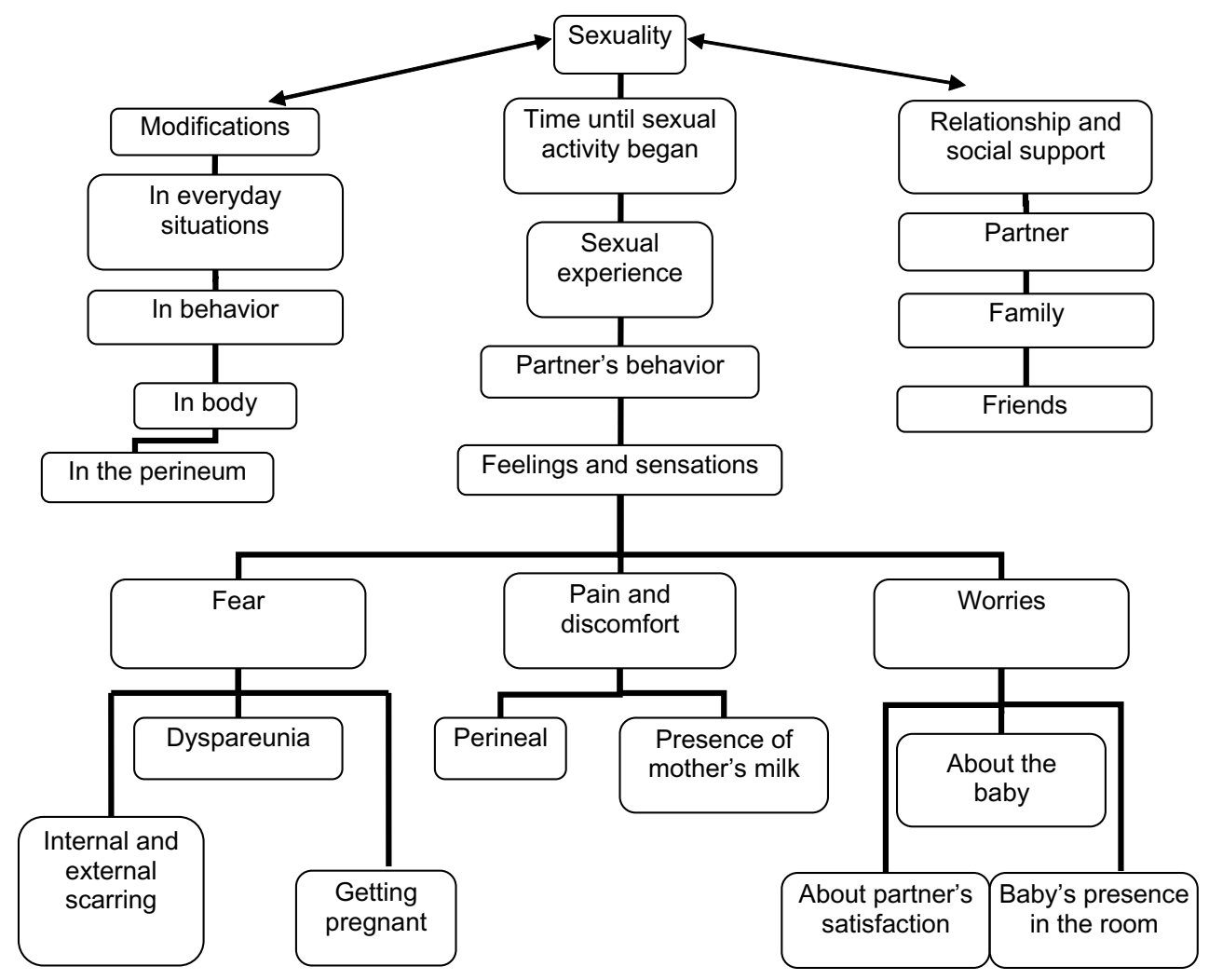

Figure 1 - Representations of categories

\section{Modification}

The women talked about change in everyday situations, in routines and in their responsibilities on becoming mothers. These changes are reported as crisis situations and ones of being temporarily thrown offbalance due to the change in their routine and personal habits: My life changed because it now revolves around him. If I want to do whatever at a given time, I have to wait for him. In the first month I didn't manage to take a proper shower, and ate while he was suckling. (E5)

They recount changes that occurred in their forms of behavior after the birth of their children. Some said they became more anxious while others said they became calmer: So I am a person who has changed a lot. I was stressed out and jumpy but I became a lot calmer after I had her. She has calmed me down. (E3)

With respect to changes in their bodies, some women report negative feelings after giving birth. In the accounts some women gave, it can be observed that this dissatisfaction with their own body had a negative influence on their sexual life. They report feeling embarrassed by their own body and not feeling at ease in front of their partners: When I lie down, I do so on my side so he can't see me. He quarrels with me and says that I am being silly. But I know that I have changed, but for him it is as if it did not make any difference. (E3)
As to the change in the perineum, the women reported their concern about its recovery, as well as about caring for their body: I healed very fast which surprised me very much. The stitches came out quickly. I didn't feel any pain because I also looked after myself. (E6)

\section{Sexuality}

The time for resuming sexual activity during the puerperium was reported as an important factor and of relevance to women. Some women related the reason for waiting to external sources of information, such as television and doctors. However, it can be observed in the women's reports that the most important factor for them in the waiting period until resumption of sexual activity is respect for one's own body clock (a statement from a woman), i.e., the particular physical and emotional well-being of each individual.

I think it depends on each woman! There are women who do it even before the 40 days are up. I think it depends on how each thinks, on the psychological side[...] (E5)

I think a woman must take time out after delivery. She has to respect her body clock[...] I don't think the body is ready, everything in its own good time, I don't know, I don't understand. (E2)

It is important to note that all the women who took part in this study had received stitches in the perineal 
region. Fear was present in the return to sexual activity of these women and was shown to be associated with the external healing of the perineal region which had received stitches, internal uterine healing, with possible pain during the first sexual encounter and also with the possibility of a new pregnancy.

In the following statements, the women talked about the first sexual experiences they had after delivery: A messy business. It was only once after the delivery that I plucked up courage, it was horrible, it was horrible. (E5) Our sexual activity went down a lot, I miss It because there is a difference. We did it a lot at the very beginning of pregnancy and now we hardly do it all. (E3)

Although the statements above show that for the women, their experience of sex was not good after delivery, for this woman it was different, better than before: It was better, it was more fun, because everything changes [...] there are lots of new things, the sensation is different. (E6)

In the statements below, the partners' behavior before resuming sexual activity showed they wanted to have sex before the women themselves felt ready and wanted to resume their sexual life. In this statement, we can see that in spite of wanting to have sex, the partner understood the view of the woman: He was after it. As far as he was concerned, it could already have happened. He asked me for it after 20 days, but I said that it was not on, and he understood. (E4)

For this woman, her partner wanted to have sex and she did not. She relates this desire to the fact that he is a man and therefore always wants to have sex: $\mathrm{He}$ was all for it before me; I was indifferent to it. He wants it all the time; it's sad that men are like that. (E5)

The women mentioned fear, worry, pain and discomfort after delivery. These women were afraid that their internal cicatrization had not been completed yet.

I was scared of the stitches because the ones outside dried up, but what about those on the inside? I was afraid they would come loose, but I think it was something in my head, but then again, afterwards it was normal, it was great. (E2)

What their women friends said regarding their first experience after childbirth made these two woman feel afraid of resuming their sex lives. This fear was associated with the pain that their friends felt: $I$ was afraid to get on with it, because my friend said that she went through horrors, that the pain was terrible. I was afraid. I kept out of his way. (E3)

The fear of getting pregnant was also present in the sexual life of the women as we can see in the statement below: I think I was more afraid of becoming pregnant again because I felt no pain as such. (E5)
The worries present in the sexual life of these women were related to the care that babies require, to the presence of the baby in the bedroom during sex and to satisfying their partners. In the statement of some women, you can see that priority is given to looking after the baby and only after that to having sex with her companion. The presence of the baby in the bedroom during sexual intercourse is a cause of concern. One of the participants recounts that for her, the fact of having sex in the same room as the baby sleeps means a lack of respect for the child: The baby sleeps with us and I think that is horrible; I think its the pits; I think it shows a lack of respect for him; I don't know if it's something to do with my brain, even during pregnancy I was embarrassed to do it because he was there. (E5)

These women were worried about satisfying their partner, in knowing whether intercourse was like it was before the baby was born, if the perineal region continued to be like it was before: I was embarrassed to ask him if it was good for him, so I asked: Is it as tight as normal? Then he said it was normal. (E2)

Pain and discomfort during intercourse were associated with the stitches and healing of the perineal region after child-birth: I thought I had an internal stitch, because I felt something bothering me in there. I think the ones inside messed it up, bothered me, because you can feel them, you know. (E5)

The women reported discomfort in relation to the presence of breast milk during sex. On the other hand, their companions did not mind the presence of milk and wanted to touch their breasts and try the milk: He takes the contrary view. It's me who doesn't like it because the milk leaks out so he says to me: no problem, because I want to touch you, but that's disgusting I say, then he quarrels with me.(E2)

\section{The role of relationships and importance of social support}

For these women, sexuality is an issue relevant to the couple and the problems must be resolved between them. Dialogue with their partner proved to be very important for the relationship.

The women talked about the participation of family and friends in their sexual experiences and daily life. One of the women talked about the importance of the lessons that her mother gave her about sexuality, mainly because she and her partner are inexperienced: She (Mom) was always one to explain things; I think this was very important to me. (E2)

The participation of friends who have had the experience of having normal delivery was considered important: I always asked my friend because she had had 
a normal delivery, but she did not like to talk about her sex life. (E6)

\section{Discussion}

The birth of a child can be considered an event of great impact for a woman on different facets of her life. The bodily and hormonal modifications that occur during the postpartum period are widely known and are experienced by women not only on the physical plane but also in terms of feelings, in the way they look at themselves and how they make relationships in society. Dealing with these changes is related to subjectivity and their perception of their own bodies and themselves.

It can be observed, through this study, that the perceptions that the women have about their bodies in the post-partum period are linked to the ideology of the biological body, because the women felt uncomfortable with their bodies and this affected their self-esteem, selfimage, sexuality and relationship with their partners.

For some women the physical changes suggest a concern about and giving value to self-esteem, while others see the process as an expected evolution ${ }^{(7)}$. Thus perceptions of the body in the puerperium are related to the way that each woman deals with the changes occurring in her body, a matter of subjectivity, set in the context of relationships and the culture of each woman.

Sexuality is integrated with this whole new process a women experiences, whether in relation to herself, to her body and femininity or to the contact and communication with her partner. It is built up all through the life of the subject in different ways. It can be said that sexuality is not static. As a constituent part of the subject, it will undergo changes to the extent that the individual has new experiences. It is thus understood that sexuality is not limited only to the sexual relationship or reproduction, but is integrated into the individual's life in all $\operatorname{areas}^{(8)}$.

Most information found in the literature regarding the return to sexual life of women in the puerperium says this return should occur after the forty-third day of the postpartum period or two weeks after the delivery, in accordance with the comfort and desire of the woman ${ }^{(9)}$.

Some women in the postpartum period take a long time to feel sexual desire, for they need time to reconnect with their bodies and feelings(10). It is through experience that one has access to one's own nature $^{(11)}$. In this context, it can be stated that besides the information provided in books and by professionals, there is the subjectivity of each individual and the selfknowledge about one's own body. Women may not have scientific knowledge about uterine involution or hormonal processes that occur in the puerperium. However, it can be seen from this study that for them the most important matters were their physical and psychological well-being and "respect for their body clock" (as stated by one of the women interviewed). This is empirical knowledge about oneself, and this issue was the main and most relevant one to women when they returned to sexual life after child-birth: feeling ready and feeling their body is ready for a new stage.

Pain felt in the body during sexual intercourse interferes with female sexuality, both by being harmful to sexual health and to the conduct of the relationship, thus causing dissatisfaction in women ${ }^{(12)}$.

It can, therefore, be seen that in professional obstetric care professionals are failing to take a broad look at the sexuality of women in the postpartum period. This is essential to the practice of protecting the perineum, and it is of fundamental importance that women know what an episiotomy is, why it is recommended and what the consequences are ${ }^{(13)}$. Routine episiotomy should not be a usual practice, once the evidence shows it may damage women. This procedure is indicated only in cases of: fetal distress, slow labor progression and threat of, or previous, third degree laceration ${ }^{(14)}$.

During the puerperium, the low motivation for sex and the subsequent decrease in frequency have been widely supported by the fact that women experience pain and discomfort during penetration ${ }^{(15)}$.

Some of the participants of this study pointed out their concern about the baby being present in the room while having sex with their partners. This concern emerged when one of the woman said she considered this to show disrespect for the baby because the baby's presence when she is having sex upsets this woman even if the baby is sleeping. Thus it can be seen that for her the baby is a conscious being which already has intellect and perception and therefore should not witness the sexual relationship of his parents, since sexual relations belong to the adult phase of life.

In some statements, one can see the concern of women during sexual intercourse about looking after the baby and being afraid that it might wake up. One of the interviewees said that before having sex, she does everything that is pertinent to looking after the baby and waits for it to go to sleep.

It is possible to see that the maternal role interferes in sexual relationships, for there is concern about the 
baby and looking after it. Dialogue and understanding between the couple during the puerperal period are shown to be of great importance. In the puerperium, some women seem indifferent to sexual matters and because of this stance, their partners react and take up positions that range from pressurizing them into the return of sexual activity to setting aside and renouncing sexual activity(10). Understanding between the couple is shown to be essential in this matter. One of them "ran away from" her partner by locking herself in another room of her home because her husband said that he would not put up with not having sex. However, others reported that despite their companions wanting to have sex before they felt ready, they reacted with understanding.

Breastfeeding can provide different sensations and feelings for women when related to sexuality. During the puerperium it is assumed that women are ready and willing to breastfeed. The expectations placed on women often prevent them from revealing their desires, their physical and emotional states; it is therefore important to reflect on breastfeeding and female sexuality(16). Given this, breastfeeding is also a social experience that will have different meanings and significances in the life of each woman.

The bodily sensations and actions that are involved in the body of a woman during motherhood are determined by cultural representations of motherhood and generate socially recognized ways to perceive and act vis-à-vis situations that appear in breastfeeding. These can be experienced by women in harmony or conflict with social determinations, thus allowing their limits to appear(17).

The process that involves the puerperium and motherhood is constructed daily in the life of women and their families. This implies changes in behavior and in family organization that take place according to the experiences and relationships in the lives of women during this period.

The women talked about the changes in their behavior and their perceptions of themselves in relation to these changes. The presence of the new being in the home, compounding the family organization, is also reflected in the form of behavior of some participants in the study. One of the informants said that, after giving birth, she became a less selfish person, which is linked to taking care of the new being who is totally dependent. Motherhood is constructed day by day, as the mother gets to know her baby. Thus, it is a learning period that reveals transformations and adaptations in the lives of women on their way to becoming mothers ${ }^{(18)}$.

All experiences take shape through relationships between subjects. The social network is strongly present in the experiences and in the construction of meanings that these experiences will bring to the life of the subject. Thus, when undergoing the puerperium, the way that women deal with their own bodies, feelings and behavior during this period of changes gives shape and meaning vis-à-vis the subjectivity, experiences and social relationships that these women have.

\section{Conclusion}

The look taken at women during the puerperium should be a broad one, one that attends to their difficulties and experiences, gets to know the cultural and social context in which they live so that taking care of them is conducted effectively. Further research, with regard to the sexuality of women in the puerperium, should be carried out so that professionals may better understand how women experience this period in order to intervene effectively, when necessary, in order to encourage women to freely recount their experiences and to prompt finding solutions to possible problems, with the assistance of medical professionals. Nurse-midwife professionals have a fundamental role because when acting directly in the women's pregnancy-puerperal cycle they can detect women's fears, doubts and problems in this area from the beginning of prenatal care in such a way that they can bring solutions to the women's issues. Thus it is very important for the women's experiences during the puerperium to be accompanied by these professionals.

\section{References}

1. Ministério da Saúde (BR). Pré-natal e Puerpério: atenção qualificada e humanizada. Brasília (DF); Ministério da Saúde; 2005.

2. Jaggar AM, Bordo SR. Gênero, corpo, conhecimento. Rio de Janeiro (RJ): Record/Rosa dos Tempos; 1997.

3. Ressel LB, Gualda DMR. Reflexões sobre a sexualidade velada na imagem da enfermeira. Rev Gaúch Enferm 2005 dezembro; 26(3):414-24.
4. Heilborn ML. Entre as tramas da sexualidade brasileira. Estudos feministas. 2006 janeiro/abril; 14(1):43-59.

5. Rubin $\mathrm{HJ}$, Rubin IS. Qualitative interviewing: the art of hearing data. California: Sage; 2005.

6. Gomes R. Análise e interpretação de dados de pesquisa qualitativa. In Minayo MCS, Deslandes SF, Gosmes R. (organizadores): Pesquisa social: Teoria método e criatividade. Petrópolis (RJ): Vozes; 2007. p. 79-107. 
7. Machineski GG, Schneider JF, Bastos CCBC. Corporeidade da mulher no pós-parto: uma compreensão da linguagem em Maurice Merleau-Ponty. Rev Gaúch Enferm. 2006 setembro; 27(3):408-16.

8. Louro GL, organizador. O corpo educado: pedagogias da sexualidade. Belo Horizonte (BH): Autêntica; 2007.

9. Cunningham FG, MacDonald PC, Gant NF, Leveno KJ, Gilstrap LC, Hankins GDV, et al. Williams obstetrícia. Rio de Janeiro (RJ): Guanabara Koogan; 2000.

10. Abuchaim ESV, Silva IA. Vivendo la lactancia y la sexualidad em la maternidad: dividinéndose entre ser madre e mujer. Ciênc Cuidado Saúde. 2006 maio/agosto; 5(2):220-8.

11. Gualda DMR. Eu conheço minha natureza: um estudo etnográfico da vivência do parto [tese]. São Paulo: Escola de Enfermagem, Universidade de São Paulo; 1993.

12. Gerin L. A ocorrência de Dispareunia entre mulheres: como fica a saúde sexual? [tese]. Área de concentração: Enfermagem em saúde pública. Ribeirão Preto (SP): Escola de Enfermagem de Ribeirão Preto, Universidade de São Paulo; 2008.
13. Previatti FJ, Souza VK. Episiotomia: em Foco a visão de Mulheres. Rev Bras Enferm 2007 março-abril; 60(2):197-201.

14. Silva AI, Figueiredo B. Sexualidade na gravidez e após o parto. Psiquiatr Clín [periódico online]. 2005 [acesso em 21 maio 2009]; 25(3):253-64. Disponível em: http://hdl.handle. net/1822/4720

15. Organização Mundial da Saúde. Maternidade segura. Assistência ao parto normal: um guia prático. Genebra (SUI): OMS; 1996.

16. Monteiro JCS, Gomes FA, Nakano AMS. Amamentação e o seio feminino: Uma análise sob a ótica da sexualidade e dos direitos reprodutivos. Texto Contexto Enferm. 2006 setembro;15(1):146-50.

17. Nakano AMS. As vivências da amamentação para um grupo de mulheres: nos limites de ser "o corpo para o filho" e de ser "o corpo para si". Cad Saúde Pública 2003;19(Supl.2):355-63.

18. Badinter E. Um amor conquistado: O mito do amor materno. Rio de Janeiro (RJ): Nova Fronteira; 1985. 